\title{
Pinocchio, the Emotion of Shame and the Influence of Greek Thought
}

\author{
By Simonetta Milli-Konewko*
}

\begin{abstract}
Considered a canonical piece of children's literature and one of the greatest works of Italian literature, The Adventures of Pinocchio written by Carlo Lorenzini is a universal icon that had a significant effect on world culture. According to Fondazione Carlo Collodi in 1990s the book has been adapted in 260 languages worldwide and, as of 2018, translated in 300 languages. The book offers a metaphor for the human condition and the historic time in Italy. This study analyzes Lorenzini's work through the emotion of shame and the influence of Greek classical literature. Shame, perceived as an act considered socially improper, is communicated by lowering the eyes as if to stop communication with others. But specifically, how does Lorenzini employ shame and for which reason? Which are the circumstances activating this emotion? To analyze these questions and others this article considers theoretical discourse on shame established, among others, by scholars of the emotions such as Aristotle, Dodds and Tomkins.
\end{abstract}

\section{Introduction}

It was widely demonstrated that the Mediterranean culture has recognized, along the centuries, the values of honor and of shame as basic elements of its civilization. Studies by Barton, Horden and Purcell give us a wide demonstration of that component. ${ }^{1}$ Carlo Lorenzini/Collodi ${ }^{2}$ by validating the premises of this ancestral tradition, writes The Adventures of Pinocchio permeating it with such values. Collodi's masterpiece was first published, from 1881 to 1883, in the Newspaper for children (Giornale per bambini) ${ }^{3}$ but, as Prezzolini declares, is a story for adults, a "tasting stone for foreigners," which communicates that sense of Italiennes. Those who understand Pinocchio's beauty, also understand Italy. ${ }^{4}$ In agreement with this point of view, some scholars underline the epic character of

"Associate Professor, University of Wisconsin-Milwaukee, USA.

1. Carlin Barton, Roman Honor: The Fires in the Bones (Berkeley, CA: University of California Press, 2001), 13; Peregrine Horden and Nicholas Purcell, The Corrupting Sea: A Study of Mediterranean History (Oxford, UK: Blackwell, 2000). All translations from the English texts are mine.

2. Collodi is the pen name used by Lorenzini to honor his mother's birthplace. See Carlo Collodi, The Adventures of Pinoccho, ed. Nicolas J. Perella (Berkeley, CA: University of California Press, 1986).

3. In the framework of literature for young people, many critics underline the originality of Collodi's text. See, e.g., Collodi, The Adventures of Pinocchio.

4. Giuseppe Prezzolini, La Cultura Italiana (Italian Culture) (Florence: Società Editrice La Voce, 1906), 185. 
the novel, suggesting some similarities between Pinocchio and Ulysses, Aeneas, Christ, Dante, Mazzini ${ }^{5}$ (Toesca, Wunderlich, Morrisey, Biffi). Beyond the multitude of different editions, reworked versions and rewritings of the story, ${ }^{6}$ a huge amount of critical material has been produced to support its comprehension. Bertacchini has collected the opinion of several scholars who have explored the issue whether the Italian national identity can be traced back to this text, or Italian people are really a population grown through the pains and sorrows experienced by Pinocchio. ${ }^{7}$ Spadolini, for example, by reconsidering the history of Italy through its most meaningful characters in the fields of theory, literature and politics, declares that Collodi's text offers Mazzini's philosophy about man's duties. ${ }^{8}$ According to Spadolini, Pinocchio's final salvation is to be found in the acquired notion of work and commitment, which Pinocchio can learn. This essay will demonstrate how Collodi uses the emotion of shame to build up Pinocchio's identity, to help him through his education to gain the values and virtues of the ideal citizen in the just constituted Italian Nation. I am going to examine Collodi's novel keeping in mind the theoretical studies on shame by - among others Plato, Aristotle, Sophocles, Tomkins and Dodds.

E. R. Dodds in Greeks and the Irrational dedicates the first two chapters to a clarification of the culture of shame. According to the scholar, the society described by Homer was ruled by the feeling of shame, rather than the feeling of fear. The warriors' behavior and their dedication to their mission were regulated by the sense of honor. The desire to maintain their sense of decorum at high levels, and the consequent concern for public disdain disciplined their conduct and prompted them to maintain their perception of duty at a high level. ${ }^{9}$

Confirming Dodds' approach, the Apology of Socrates, written by a young

5. Pietro M. Toesca, "La Filosofia di Pinocchio Ovvero l'Odissea di un Ragazzo per bene con Memoria di Burattino" ("The Philosophy of Pinocchio or the Odyssey of a Good Boy with Memory of Puppet"), Forum Italicum 31 (1997): 459-86. Richard Wunderlick and Thomas Morrisey, Pinocchio Goes Postmodern: Perils of a Puppet in the United States (New York, NY: Routledge, 2002); Giacomo Biffi, Contro maestro Ciliegia. Commento Teologico a "Le avventure di Pinocchio" (Against master Cherry. Theological Commentary on "The Adventures of Pinocchio") (Milan, Italy: Jaca Book, 1977).

6. See, e.g., Giorgio Manganelli, Pinocchio. Un Libro Parallelo (Pinocchio. A Parallel Book) (Milan, Italy: Adelphi, 2002). Umberto Eco, Povero Pinocchio (Poor Pinocchio) (Verona, Italy: Comix, 1995); Stefano Benni, "Pinocchia," in Teatro 2 (Milan, Italy: Feltrinelli, 2000).

7. Renato Bertacchini, Le "Avventure" Ritrovate: Pinocchio e gli Scrittori Italiani del Novecento (Recovered "Adventures": Pinocchio and the Twentieth Century Italian Writers) (Pescia, Italy: Fondazione Nazionale "Carlo Collodi," 1983).

8. Giovanni Spandolini, La mia Firenze (My Florence) (Florence, Italy: Le Monnier, 1995); Giovanni Spandolini, Gli Uomini che Fecero l'Italia (Men Who Made Italy) (Milan, Italy: Tea, 1999).

9. Eric Robertson Dodds, Greeks and the Irrational (Berkeley, CA: University of California Press, 2004). 
Plato and highlighting Socrates' ideas, underlines the role played by the feeling of shame in the philosopher's life and philosophical mission. Plato reports that Socrates' speculative discussions enhance the value of shame, perceived as a fundamental emotion in order to lead a good life. Plato writes that Socrates, not knowing the distinction between teacher and pupil, invites the Athenians to overcome their cognitive shame and recognize gods knowledge. According to Socrates, the only shame that can be considered appropriate is the sense of humility originated by the awareness of how irrelevant human knowledge is and by the feeling of reverence and dread towards gods' wisdom. Socrates instills shame in the Athenians, since they do not know the right principles of a moral and intellectual life and focus their attention on gathering material wealth and other futilities. ${ }^{10} \mathrm{He}$ therefore claims that we need to preserve the honor of shame, that is: we should be ashamed when we give stronger importance to apparent rather than inner honor. Therefore, the shame he refers to concerns the emotional involvement of a person facing himself/herself and his/her conscience.

Some scholars underline the physical features that go together with shame, and they often connect it with a juvenile behavior. In the fourth book of the Nicomachean Ethics, Aristotle combines the concept of shame with that of modesty, and he describes it "as a sort of fear towards dishonor, which produces effects that are very similar to those created by fear for some dangers. In fact, those who feel ashamed, get red, while those who are afraid of death, turn white."11 Aristotle describes it as a passion that only suits youth, since mature men should never perform a shameful action. Moreover, "shame is not characteristic of the virtuous man, if it is true that it raises as an effect of bad deeds (such deeds cannot be performed. Then, if some of them are bad, and others are considered as such by the opinion of people, that makes no difference: either the first ones or the second must not be performed, so we will not feel any shame ${ }^{12}$ )." The shame suggested by Aristotle is an emotion that characterizes the individual who is not psychologically mature, yet. For this reason, he is not able to take mindful choices.

Other studies, although enhancing the meaning of the introspective side of this emotion, have also highlighted its connection with the outer world. Silvan Tomkins observes the personal nature of this emotion, when he informs us on how shame is, in contrast to all other affections, and experience of the self. When a person perceives shame, he/she feels it as an illness of his/her personality, and he/she feels it on his/her face - site of his/her bright eyes -

10. Plato, Apologia di Socrate (Socrates Apology) (Milan, Italy: Bompiani, 2000), 9.

11. Aristotle, Etica Nicomachea (Nicomachean Ethics), ed. Claudio Mazzarelli (Milan, Italy: Bompiani, 2000), 9.

12. Aristotle, Etica Nicomachea, 9. 
because that is the place where the self is expressed..${ }^{13}$ On the other hand, the scholar analyzes shame also in connection with an individual's ability to be in relation with the others. He claims that this feeling represents a non-punitive answer to what is interpreted as a temporary interruption of communication. ${ }^{14}$ Moreover, Tomkins offers a kind of behavior connected to this emotion. Shame, felt as a feeling of failure and unworthiness, is a helping affection for interest and excitement, and is expressed by lowering the eyes, losing facial expression and releasing the neck's muscles, making our head bend down. ${ }^{15}$

\section{Models of Shame}

Pinocchio's growth from a wooden marionette to a boy goes through several steps, which teach and have their peak in the separation of the two entities in the final part of the story, when Pinocchio - amused by the sight of the marionette - is aware of his completed transformation. Collodi offers multiple occasions where Pinocchio is invited to grow from an emotional point of view, but every time it seems he does not recognize them. Pinocchio must accept his growth itself in order to become aware that he is not a marionette, but a free man.

On his search for Geppetto, Pinocchio arrives in the village of the Busy Bees, used by Collodi to represent the importance of commitment and work. While every person is active and bound to their occupation in that place, Pinocchio keeps refusing any task that is offered to him. Feeling the torment of hunger, he then thinks about begging.

Remembering Geppetto's teaching, the marionette knows very well that the only people deserving assistance are those who are condemned - because of their age or for illness - to the inability to work. Therefore, only "old and invalid ones"16 have the possibility to beg for mercy. Doing that would have been, for a young individual like Pinocchio, a shameful act.

The marionette does not adapt to Geppetto's teaching and when he sees a sweaty and flushed man carrying two carts full of coal, he chooses the shortest path in order to satisfy his hunger. "Pinocchio, considering him from his physical aspect as a good man, approached him and, lowering his eyes for the shame he felt, whispered: Could you mercifully give me a coin, because I feel

13. Silvan S. Tomkins, Shame and Its Sisters, ed. Eve Kosofsky Sedwick and Adam Frank (London, UK: Duke University Press, 1995), 134.

14. Tomkins, Exploring Affect. The Selected Writings of Silvan S. Tomkins, ed. E. Virginia Demos (Cambridge, UK: Cambridge University Press, 1995), 267.

15. Tomkins, Exploring Affect, 267.

16. Collodi, The Adventures of Pinocchio, 274. 
like I am starving?" 17 The man confirms Geppetto's principles: "Not a coin, the coalman answered, but I'll give you four, on condition that you help me dragging these two coal carts to my house."18 In half an hour Pinocchio asks other twenty people for money, but they all answer: "Aren't you ashamed? Instead of going around as a dawdler, go and look for a job, and learn how to gain your living!" 19

In these examples Collodi describes a kind of shame that follows the behavioral pattern suggested by Tompkins. Pinocchio, feeling his own discomfort in performing an act that is not considered socially correct, expresses his anguish by lowering his eyes, almost as if willing to stop his communication with the others. By revealing the tight connection between shame and social behavior, the marionette feels shame, because he is aware that he has broken some cultural and behavioral rules.

It has often been declared that, speaking about shame, it is not the sensation itself, rather the authority that is outer. If the authority has been internalized, and if its rules or rituals are disobeyed, the individual loses his/her honor. For this reason, we can easily understand the strict consequences linked to remarkable transgressions. In fact, when the rules broken by an individual's actions are considered important in the structure of values of a community, then the judgement pronounced by others produces isolation and banishment. Heller's comparative study on shame and conscience is significant in order to understand the connection between shame and society. According to this scholar, shame is different from conscience, since these two emotions answer two different authorities. While the authority is, in the case of conscience, reason - a sort of inner voice - in the case of shame it is social customs, that is the set of rituals, habits and behavior rules that represent "other people's eyes." 20

\section{Greek Patterns of Shame and Behavioral Standards}

The Iliad offers clear examples, which explain how the feeling of shame is closely connected with the behavioral values that characterize a society. Through its protagonists - Hector and Diomedes - Homer conveys the implications pertinent to such emotional condition. Their decisions reveal the system of values that governs their demeanor. In a famous scene taken from Book Six, Andromache invites her husband Hector not to fight again, since her parents

17. Collodi, 274 .

18. Collodi, 274.

19. Collodi, 274.

20. Agnes Heller, The Power of Shame. A Rational Perspective (London, UK: Routledge \& Kegan Paul, 1985), 5. 
and siblings are dead and he represents the only family she has, now.

Andromache begs her husband for mercy looking at her condition. She is afraid of becoming a widow and does not want her children to be orphan. ${ }^{21}$ Hector, although sharing his wife's concern, does not take into consideration her personal needs. He is aware of the emotional consequences caused by the decision his wife has suggested. In fact, if he avoided the war like a coward, his shame among Trojan people would be too heavy to bear. ${ }^{22}$ Andromache does not react to her husband's answer, thus showing the importance of public opinion in that historical background. Hector thinks he will feel ashamed, therefore losing the respect of Troy's citizens, if he fails to fulfill a precise obligation. This potential shame becomes an important instrument to measure and respect the values of his community.

In a similar way, Collodi represents the emotion of shame to describe the importance of other people's judgement and to underline how personal behavioral rules, not shared by the community, are broken. While Homer only imagines the emotion of shame and a consequent loss of respect, Collodi directly represents the negligence when it has already happened. They both clarify the importance of showing socially responsible demeanors, respecting other people's rights. They both describe the importance of taking into serious consideration one's own commitment, be it a war or working activity. While the Greek writer enhances the participation in the war as something promoting honor, Collodi suggests work commitment as an honorific value in the future of the new Italian Nation. The importance of this value is confirmed by the first article of the Italian Constitution, chosen by the fathers of the Constituent Assembly to highlight the working activity as a necessary basis of the new Italian State, rising after the tragedy of the war, thus confirming Collodi's precept. ${ }^{23}$ "Italy is a Democratic Republic, based on work. People have sovereignty on it, and they perform it in the forms and within the limits of the Constitution." 24

Collodi does not use the emotion of shame only to divulge behavioral rules, but also to teach moral values. When Pinocchio finally seems to be reasonable and resolved in becoming a good boy, he probably faces his biggest temptation: following his friend Candlewick to the Land of Toys, where they can be free from any constriction and duty. After months of revelry, the two friends realize the consequences of their choice. The Land of Toys is a place of deceit,

21. Homer, The Iliad, ed. Herbert Jordan (Norman, OK: University of Oklahoma Press, 2008), 6431.

22. Homer, The Iliad, 6441.

23. The film created by Institute Luce in 1961 to celebrate the first fifty years of the Italian Unity confirms the importance of work as a form of progress for the commonwealth of the Nation. L'Unità d'Italia, Cinecittà Luce, 1961.

24. See Giorgio Ferrari, ed. Codice Civile (Civil Code) (Milan, Italy: Hoepli, 2010). 
because it transforms the young people living there into donkeys. When Pinocchio looks at his body that is slowly turning, he is desperate and ashamed. "He soon went and looked for a mirror, filled the basin with water and looking at his image mirrored there, saw what he would have never wanted to see that is, his image adorned with a great pair of donkey ears. I let you imagine poor Pinocchio's sorrow, shame and desperation!"25 The immediate reaction to such disorientation is a personal outburst: "He started crying, shouting and hitting the wall with his head: but the more he was desperate, the longer his ears grew, grew, grew and got furry towards their end." 26 Collodi reintroduces Aristotle's elements that give a definition of shame. Young Pinocchio, not being a mature and virtuous man yet, is vulnerable to shame, since he I not yet able to distinguish respectable circumstances from unworthy ones. He is overwhelmed by dejection and mortification when, looking at his reflection in the mirror, sees the donkey ears that mark, in this case, the feeling of shame instead of the facial blush considered by Aristotle.

The donkey ears become therefore the symbol of Pinocchio's transgression, of his inability to adapt himself to defined rules. Pinocchio feels ashamed because he has betrayed the Fairy's trust. While the woman wanted to celebrate his realization, Pinocchio has escaped another time, refusing his responsibilities again. With this example, Collodi condemns the marionette's decision and enhances the importance of a believable behavior, respectful of other people's feelings. Values such as loyalty and reliability are suggested as leading characteristics of the new Italy.

\section{The Social Value of Shame}

In the beginning, the writer presents shame as an individual event, while he later describes it as a social event. Pinocchio, after discovering and making direct experience of the deceit of the Land of Toys, understands his failure and would like to convince of that also his friend Lucignolo. However, he finds at first difficult to show his condition: "And he seemed to be willing to go out. But when he was at the door, he remembered he had donkey ears and, ashamed to show them in public, what did he think up? He took a big cotton hat and, after wearing it, he pulled it down, under the point of his nose. ${ }^{27}$ As it is underlined more than once, shame arises the fear of being found, and therefore pushes people to go and hide themselves. Pinocchio's new condition, exemplified here by the physical transformation, is an obstacle because it is the sign of the violation and of a new position, thus more indeterminate and uncertain.

25. Collodi, The Adventures of Pinocchio, 372.

26. Collodi, 372.

27. Collodi, 372. 
It was often underlined that "Shamed people dislike themselves and want to change, hide, or get rid of the self." 28 With the symbol of the donkey ears, and then with the complete transformation into a donkey, Collodi shows the implicit consequences associated with individuals' realization of their inadequacy and their desire for a change of both their physical appearance and conscience; the connected feeling of mortification expresses the adventure towards different spaces and the realization of how an individual is seen by others.

After making Pinocchio and Candlewick meet and talk about their homonymous misfortune, Collodi describes their dramatic transformation: "And while they were speaking, they both bent on all four on the ground, walking on hands and feet, swirling and running around the room. And while they were running, their arms became paws, their faces widened and took the shape of animal heads, and their backs filled with a grey, black and white fur." ${ }^{29}$ The author then describes the culminating moment of their transformation process, by introducing the feeling of shame as distinguishing element of the event: "However, do you know what the worst moment was for those two scoundrels? The worst and most humiliating moment was when they felt a tail appearing behind them. Defeated then by shame and sorrow, they tried to cry and complain over their destiny." 30 Their mortification is enhanced when not just their physical aspect changes under their eyes, but also their voice becomes animal-like: "Had they never tried to do it! Instead of whimpers and complains, they emitted donkey brays. And soundly braying, they both sang heehaw, heehaw, heehaw."31

With this painful transformation, Collodi clarifies the social value of shame. The protagonists' anguish is originated by the materialized sight of what society saw in them. The transformation makes their choice and previous behavior apparent. In this context, shame is raised by their realization of the outer judgment. According to Sartre, shame is not a feeling raised by mere individual thought, but needs, on the other hand, other people's consideration. ${ }^{32}$ Pinocchio's shame, ascribable to the consideration the marionette must hold for the others and to the value given by others to his demeanor, shows the respect for the complex rules that regulate the relationships among new Italy's citizens.

The shame suggested by Collodi is in tight connection with the surrounding environment. Once turned into a donkey, Pinocchio is thrown at sea, and after being eaten by the fish and having gained his marionette shape again, he

28. Todd Kashdan, The Upside of Your Darkside: Why Being Your Whole Self - Not Just Your "Good" Self-Derives Success and Fulfillment (New York: Hudson Street Press, 2004), 3.

29. Collodi, The Adventures of Pinocchio, 384.

30. Collodi, 384.

31. Collodi, 384.

32. Jean-Paul Sartre, Being and Nothingness, ed. Haze E. Barnes (New York, NY: Routledge, 2003), 246. 
confesses his story to his buyer, revealing that he was transformed into a donkey, complete with tail and ears, when he fled from his home, following bad companies. Pinocchio communicates the shame he felt after this transformation: "What a shame that was for me!...A shame, my dear owner, that I hope Holy St. Antony won't make you feel!" 33 The marionette describes then in detail the reasons of this shame: "Led to the donkey market to be sold, I was bought by the Director of a horse company, who decided to turn me into a great dancer and hoops jumper. But one night, during the show, I fell and was then with a limp on both legs." 34 Collodi describes with this example Pinocchio's mortification in becoming a public character, having to show his transformation to the outer world. As previously underlined, while shame usually reveals itself as a feeling of temporary detachment from other individuals, Collodi's example highlights, on the other hand, the union between the marionette and the community. Originated by other people's opinion as a manifestation, shame as Collodi intends it is shown towards the others, thus underlining the importance of accepting a vision of reality, although in contrast with our own.

Collodi does not use the emotion of shame only to make the relationship with the others easier; he also uses it as an instrument to know ourselves. After the visit by the doctors, having taken the medicine and avoided his death, Pinocchio tells the Fairy several more lies and sees his nose grow longer, to the point he is unable to move. Pinocchio senses the Fairy's incredulity when she laughs at him and offers him an explicit explanation of the types of lies an individual can fall into: "...there are lies that get you nowhere, and lies with a long nose: yours are precisely of this second kind."35

The Fairy's skepticism generates the marionette's mortification: "Pinocchio, with no idea about where he could shamefully hide, tried to flee from the room, without being able to do it. His nose had grown so much, that he couldn't go through the door."36 The discovery of his lie allows him to focus on his behavior. The shame he feels enables him to develop awareness of his actions. Lewis says that emotions can be classified according to the relations they create with themselves. While some emotions - like fear, happiness, anger - do not require an inner exam, other emotions - like jealousy, envy, empathy, shame - need this inner analysis. For this scholar, the difference between the two groups of emotions consists in this self-referentiality. ${ }^{37}$ The relation between shame and self-consciousness was further underlined in classical Greek works. The Oedipus Rex, for instance, written by Sophocles around 430 B.C., conquered generations of people and involved several

33. Collodi, The Adventures of Pinocchio, 408.

34. Collodi, 408.

35. Collodi, 210.

36. Collodi, 210.

37. Michael Lewis, Shame: The Exposed Self(New York, NY: The Free Press, 1992), 19. 
scholars who wanted to fully understand its meaning. Oedipus, after killing his father and marrying his mother, reacts with a performance of violent imposition: he blinds himself and explains his behavior with the following words: "I don't know - if I could see - what sort of eyes I would have looked at my father with, once he descended into the Hades, or my miserable mother. Towards both of them I have committed actions for which hanging me would not have been enough. Or maybe I could wish the sight of my children, born as they were? No, really, never, for my eyes. Nor the city, nor the walls, nor the sacred images of the gods." 38 According to this model, the protagonist's shame highlights his awareness and is connected to the feeling of responsibility towards his behavior. In fact, it was observed that shame can be related to fear: "...the structures of shame contain the possibility to control and learn from fear, since they give an understanding of ethnic identity of an individual that gives no meaning to fear when the two are reciprocally related."39

Oedipus, filled with anguish for not being able to avoid the oracle that was suspended over him since he was born, according to which he would have killed his father and married his mother, blinds himself with the buckles of the dress of the woman who was his mother and his wife as well. "In this way, screaming, he hit his eyes repeatedly, and not just once, with the buckle; and the bleeding orbs wetted his beard, not pouring liquid streams of blood, but a black rain, a bloody storm." ${ }^{40}$ With this violent act, Oedipus expresses all the remorse because of his understanding and realization of the intolerable acts he committed. Oedipus feels ashamed because he was not able to avoid his own destiny, while Pinocchio perceives this same feeling only after he has been presented with the fait accompli, demonstrating the necessity of an open confrontation in order to establish real relationships and gain the protagonist's emotional growth.

In the final chapter, Collodi describes Pinocchio's awareness, how he stops being a marionette, becomes a good boy and finally understands the importance of respecting the others. He recognizes the value of the Cricket's advices and finally, able to understand the deceits performed by Cat and Fox, he devotes himself to his father's health. In exchange for a simple glass of milk, he decides to do the effort of turning the reel of the produce seller Gingio, where he also assists the death of his donkey. Pinocchio understands the dying beast is his friend Candlewick and he cries, confessing to the man that the donkey was once one of his classmates. The farmer, full of wonder for Pinocchio's words, answers in a mocking way: "What? Gingio shouted with a sounding laugh. What?! Did you have donkeys as classmates?...Just think how much

38. Sofocle, Edipo re (Oedipus Rex) (Milan, Italy: Mondadori, 1982), 1369-75.

39. Bernard Williams, Vergogna e Necessità (Shame and Necessity) (Milan, Italy: Il Mulino, 1979), 222.

40. Sofocle, Edipo re, 1369-75. 
you should have studied!..."41 Pinocchio perceives the man's taunting and, humiliated by the farmer's reaction, stays first in silence, then he shows his attention and dedication towards his father. "The marionette, feeling mortified by those words, did not answer, but he took his glass of almost warm milk and went back to the hut." 42 Collodi clearly explains that from that moment and for months after the marionette worked hard in order to help old Geppetto. "And since that day, for more than five months, he continued to wake up every day before dawn to go and turn the reel, and earn in that way his glass of milk, which was so good for his dad's delicate health. ${ }^{43 "}$ Many events were necessary for Pinocchio's maturation, but it is significant that his change happens soon after the representation of his mortification. Collodi suggests shame as the element that triggers the marionette's redemption and his inner growth, showing how an emotional involvement can influence an individual's ethic behavior.

\section{Greek Paradigm of Shame and Moral Progress}

To understand Pinocchio's growth and the meaning of the feeling of shame, it is interesting to consider the teaching of an ancient famous Greek playwright. In Philoctetes, ${ }^{44}$ a tragedy written in 409 B.C., Sophocles introduces meaningful situations that describe shame. Transposing a previous epic myth, the author tells the deeds of the famous archer Philoctetes, abandoned by his friends on the island of Lemnos, because of a horrible wound caused by a snake. However, the Greeks come to know, through an oracle, that they will not be able to conquer Troy without Philoctetes' bow. Neoptolemus, following Odysseus' advice, pretends he has argued with the Greek leaders and tries to gain Philoctetes' trust again, obtaining in the end his bow. The deceit works, Philoctetes gives him his bow but, in the final moment, Neoptolemus regrets his behavior. He takes the bow he had delivered to Odysseus and gives it back to Philoctetes.

Neoptolemus feels ashamed for the suggested deceit, and the performance of his dishonesty marks the beginning of his moral growth and his struggle against himself. Neoptolemus, young, naïve and eager of popularity, at first obeys those who give him orders. Only in a second moment he realizes that a true person cannot be a mere instrument in the hands of others. While at first, he accepts to act against his feelings, afterwards he finds the strength to refuse that hypocrisy. His internalized feeling of shame is significant, because it expresses his

41. Collodi, The Adventures of Pinocchio, 450.

42. Collodi, 450 .

43. Collodi, 452.

44. Sofocle, Filottete (Philoctetes), ed. Pietro Pucci and Guido Arrigò (Rome, Italy: Fondazione Lorenzo Valla, 2003). 
commitment towards personalized ethical standards. Through the feeling of shame, that marks the disaster of Odysseus' cynical plan, Neoptolemus finds the strength to impose his personality and affirm the respect of a human moral.

However, Neoptolemus highlights a further aspect of shame. Neoptolemus's concern about keeping his sense of honor and decorum towards himself at high levels does not support the selfish chase of self-confirming aims. On the contrary, the anguish of safeguarding his own dignity generates apprehension for another individual. Because of his perceived shame, Neoptolemus develops a behavior that is respectful of other people's principles and inclusive of different ways of behaving. Shame highlights, moreover, the illegitimacy of a behavior that does not respect an individual's deep parameters and seeks success through indecorous, inadequate and improper means.

In the same way, although Pinocchio's maturation happened because of several conflictual steps and humiliating conditions, his spiritual growth immediately follows the representation of a mortifying situation for the marionette. The farmer Gingio's mockery initially generates the marionette's silent shame, a reflection upon his past, then his generous action towards his father, and finally his definitive transformation. Like Neoptolemus' shame, also Pinocchio's feeling highlights not just his mistake in following the Cat and Fox's plans, everlasting tempters for the marionette, but also the starting point for his moral growth and the struggle against himself. The young and inexperienced Pinocchio, like the Greek hero, is at first fascinated by the various seductions of life and, although understanding the several mistakes he has done, he is always overwhelmed by promises of richness or easy situations. Both protagonists are not able, at first, to identify themselves with the others' condition, since they are only interested in their personal satisfaction. The mortification for their default suggests the awareness of other people's sorrow and the ethic growth of their personalities through right and acceptable means, which respect other people's needs.

\section{Results}

Although inferring the values of a society from the exam of the representations of shame and of the marionette Pinocchio seems difficult, critical studies have widely demonstrated that emotions are socially and culturally built. ${ }^{45}$

Moreover, it was also demonstrated that emotions, as source of knowledge, are in tight connection with values, and therefore they do not just change from

45. Catherine Lutz's work widely demonstrates that, Unnatural Emotions: Everyday Sentiments on a Micronesian Atoll and Their Challenge to Western Theory (Chicago, IL: University of Chicago Press, 1988). 
a culture to another, but they undergo evolutions within those same cultures. ${ }^{46}$ Aristotle clarifies this element in his Rhetoric, when he teaches young orators how to incite a particular emotion in their public. According to the Greek philosopher it is possible to urge or subdue emotions through the listeners persuasion on specific elements connected to their condition. ${ }^{47}$ For example, in order to generate fear, the scholar suggests convincing the public to believe in the possibility of future dangerous conditions. That shows the tight connection between emotions and principles and values.

By following the premises of the Mediterranean tradition, which recognizes honor and shame as essential qualities of their own civilization, the representations of shame in the novel Pinocchio highlight the different ways of using this emotion in order to underline values and virtues that are suggested as basic requirements for the new Italian citizens. Used by Collodi in order to highlight the importance of other people's judgment, shame can moreover underline the violation of behavioral rules that are not accepted by society. The writer uses this emotion in order to accept and propagate behaviors that are socially responsible and respectful of others, in order to teach and spread moral values such as loyalty and reliability, and to trigger the spiritual maturation of the marionette, and therefore also of the citizens of new Italy.

Collodi, justifying an individual's ability to feel shame, follows what Plato teaches in his Laws: he perceives this emotion as something which prevents man from committing dishonorable actions. ${ }^{48}$ Connected to the principles of responsibility and dignity, and suggesting Sophocles' teachings, it is meant as a mechanism of moral safety, a symptom that can trigger one's self-awareness, others' sorrow and an individual's ability to ethically improve. This way of sensing shame suggests that, if this ability were denied, the individual opposing every element that goes against his own vision of the world - could perilously diminish or even eliminate the meaning of reality.

46. Alison Jagger, "Love and Knowledge: Emotions in Feminist Epistemology," in Gender/Body/Knowledge: Feminist Reconstructions of Being and Knowing, ed. Alison M. Jaggar and S. R. Bordo (New Brunswick, NJ: Rutgers University Press, 1989), 145-71.

47. Aristotle, The Rhetoric of Aristotle, ed. Lane Cooper (New York: NY: AppletonCentury-Crofts, 1932), II 1-11.

48. Plato, The Collected Dialogues of Plato (Princeton, NJ: Princeton University Press, 1961), 647a. 


\section{Bibliography}

Aristotle. Etica Nicomachea (Nicomachean Ethics), edited by Claudio Mazzarelli. Milan, Italy: Bompiani, 2000.

Aristotle. The Rhetoric of Aristotle, edited by Lane Cooper. New York: NY: Appleton-Century-Crofts, 1932.

Barton, Carlin. Roman Honor: The Fires in the Bones. Berkeley, CA: University of California Press, 2001.

Benni, Stefano. "Pinocchia." In Teatro 2. Milan, Italy: Feltrinelli, 2000.

Bertacchini, Renato. Le "Avventure" Ritrovate: Pinocchio e gli Scrittori Italiani del Novecento (Recovered "Adventures": Pinocchio and the Twentieth Century Italian Writers). Pescia, Italy: Fondazione Nazionale "Carlo Collodi," 1983.

Biffi, Giacomo. Contro maestro Ciliegia. Commento Teologico a "Le avventure di Pinocchio" (Against master Cherry. Theological Commentary on "The Adventures of Pinocchio"). Milan, Italy: Jaca Book, 1977.

Collodi, Carlo. The Adventures of Pinoccho, edited by Nicolas J. Perella. Berkeley, CA: University of California Press, 1986.

Dodds, Eric Robertson. Greeks and the Irrational. Berkeley, CA: University of California Press, 2004.

Eco, Umberto. Povero Pinocchio (Poor Pinocchio). Verona, Italy: Comix, 1995.

Ferrari, Giorgio, ed. Codice Civile (Civil Code). Milan, Italy: Hoepli, 2010.

Heller, Agnes. The Power of Shame. A Rational Perspective. London, UK: Routledge \& Kegan Paul, 1985.

Homer. The Iliad, edited by Herbert Jordan. Norman, OK: University of Oklahoma Press, 2008.

Horden, Peregrine, and Nicholas Purcell. The Corrupting Sea: A Study of Mediterranean History. Oxford, UK: Blackwell, 2000.

Jagger, Alison. "Love and Knowledge: Emotions in Feminist Epistemology." In Gender/Body/Knowledge: Feminist Reconstructions of Being and Knowing, edited by Alison M. Jaggar and S. R. Bordo. New Brunswick, NJ: Rutgers University Press, 1989.

Kashdan, Todd. The Upside of Your Darkside: Why Being Your Whole Self - Not Just Your "Good" Self-Derives Success and Fulfillment. New York: Hudson Street Press, 2004.

Lewis, Michael. Shame: The Exposed Self. New York, NY: The Free Press, 1992.

Lutz, Catherine. Unnatural Emotions: Everyday Sentiments on a Micronesian Atoll and Their Challenge to Western Theory. Chicago, IL: University of Chicago Press, 1988.

Manganelli, Giorgio. Pinocchio. Un Libro Parallelo (Pinocchio. A Parallel Book). Milan, Italy: Adelphi, 2002.

Plato. The Collected Dialogues of Plato. Princeton, NJ: Princeton University Press, 1961.

Plato. Apologia di Socrate (Socrates Apology). Milan, Italy: Bompiani, 2000. 
Prezzolini, Giuseppe. La Cultura Italiana (Italian Culture). Florence: Società Editrice La Voce, 1906.

Sartre, Jean-Paul. Being and Nothingness, edited by Haze E. Barnes. New York, NY: Routledge, 2003.

Sofocle. Edipo re (Oedipus Rex). Milan, Italy: Mondadori, 1982.

Sofocle. Filottete (Philoctetes), edited by Pietro Pucci and Guido Arrigò. Rome, Italy: Fondazione Lorenzo Valla, 2003.

Spandolini, Giovanni. La mia Firenze (My Florence). Florence, Italy: Le Monnier, 1995.

Spandolini, Giovanni. Gli Uomini che Fecero l'Italia (Men Who Made Italy). Milan, Italy: Tea, 1999.

Toesca, Pietro M. "La Filosofia di Pinocchio Ovvero l'Odissea di un Ragazzo per bene con Memoria di Burattino" ("The Philosophy of Pinocchio or the Odyssey of a Good Boy with Memory of Puppet"). Forum Italicum 31 (1997): 459-86.

Tomkins, Silvan S. Shame and Its Sisters, edited by Eve Kosofsky Sedwick and Adam Frank. London, UK: Duke University Press, 1995.

Tomkins, Silvan S. Exploring Affect. The Selected Writings of Silvan S. Tomkins, edited by E. Virginia Demos. Cambridge, UK: Cambridge University Press, 1995.

Williams, Bernard. Vergogna e Necessità (Shame and Necessity). Milan, Italy: Il Mulino, 1979.

Wunderlick, Richard, and Thomas Morrisey. Pinocchio Goes Postmodern: Perils of a Puppet in the United States. New York, NY: Routledge, 2002. 
